\title{
Light Effects on Photosynthetic Capacity and Growth of Papaya (Carica papaya L.): A Short Review
}

\author{
Jefferson R Silva ${ }^{1}$, Weverton P Rodrigues ${ }^{1}$, Katherine Fraga Ruas ${ }^{1}$, Jessica Sousa Paixã $0^{1}$, Roberta Samara \\ Nunes de Lima ${ }^{2}$, José Altino Machado Filho ${ }^{3}$, Juan Alberto Cabrera Garcia ${ }^{4}$, Bruce Schaffer ${ }^{5}$, Julian Cuevas \\ Gonzalez ${ }^{6}$ and Eliemar Campostrini ${ }^{1 *}$
}

${ }^{1}$ Setor Fisiologia Vegetal, Centro de Ciências e Tecnologias Agropecuárias, Brazil

${ }^{2}$ Universidade Federal de Alagoas, Brazil

${ }^{3}$ Instituto Capixaba de Pesquisa, Brazil

${ }^{4}$ Instituto Canario de Investigaciones Agrarias (ICIA), Universidad de La Laguna, Spain

${ }^{5}$ Tropical Research and Education Center, University of Florida, USA

${ }^{6}$ Escuela Superior de Ingeniería Campus de Excelencia Agroalimentaria (ceiA3), Universidad de Almeria, Spain

Submission: May 08, 2018; Published: May 24, 2018

*Corresponding author: Eliemar Campostrini, Setor Fisiologia Vegetal, Centro de Ciências e Tecnologias Agropecuárias, Ecofisiologia de Culturas Tropicais e Subtropicais, Univ. Estadual Norte Fluminense (UENF), Darcy Ribeiro, 28013-602, RJ, Brazil, Email: camposternator@gmail.com

\begin{abstract}
Papaya (Carica papaya L.) is one of the main horticultural crops of many tropical and subtropical regions. The fruit is sold either fresh product or processed into drinks, jams, candies, dried and crystallized fruit, while its the enzyme papain is used for medicinal purposes. Papaya fruit is high in vitamins A and C and is a good source of calcium. Brazil is among the world's most important producers and exporters of papaya; in 2014 c.a., 1,639,300 tons of papaya was produced in 32,031 hectares of the territory. Optimum light absorption and utilization by the canopy is an important factor for maximizing papaya crop growth and productivity. Thus, knowing how papaya responds to light is important to develop management strategies to optimize fruit yield and quality. This short review aims to present the current research knowledge related to the effects of light intensity on the photosynthetic processes and growth of papaya. We demonstrate that photo synthetically active radiation (PAR) greatly affects the physiology of papaya. Understanding the interaction between light and physiological processes is extremely important for a sustainable profitable production under either greenhouse or field conditions. By using improved light science-based management, growers may optimize photosynthetic carbon assimilation and increase papaya yield and fruit quality.
\end{abstract}

Keywords: Biotic factors; Chlorophyll fluorescence; Photosynthesis; Water relations

\section{Introduction}

In $2014,63.10 \%$ of the world's total papaya (Carica papaya L.) production was concentrated in three countries, India (133.000ha and 5.699.000ton), Brazil (30.372ha and 1.424.650ton) and Nigeria (97.838 and 836.702ton) [1] In terms of productivity, the Dominican Republic, Costa Rica, Indonesia, Belize, Mexico, Brazil, and Thayland had the highest production with 287.8, 90.9, 90.6, $60.16,56.5,46.9$, and 38.7 ton of fruit ha ${ }^{-1}$, respectively.

Papaya is an important fruit crop of tropical and subtropical regions grown not only for its fruit, but also as a source of papain, a commercially valuable proteolytic enzyme that is produced in the milky latex of green, unripe fruit [2]. Evolutionarily, papain may be associated with protection from frugivorous predators and herbivores [3]. Papaya fruit is known for its high content of vitamins $\mathrm{A}$ and $\mathrm{C}$, and is a good source of calcium. On an average,
$100 \mathrm{~g}$ of ripe papaya contains 950I.U. of Vitamin A and $60.9 \mathrm{mg}$ of vitamin C (ascorbic acid) [4]. The peel of the fruit is green when immature and orange when ripe [5]. The soft reddish orange pulp has a distinct sweet flavor with a slight musk tang. The ripe papaya is normally consumed as a dessert. Green fruit and the leaves and flowers can also be used as cooked vegetables [6].

Although the exact center of origin is unknown, it is believed that the papaya is native to tropical America, perhaps in southern Mexico and neighboring Central America [7]. The center of diversification of papaya was the lowlands of Central America and southern México, and possibly West Indies (Caribbean) [8]. It is reported that seeds were taken to Panama and then to the Dominican Republic before 1525 and cultivation spread to warm elevations throughout South and Central America, southern 
Mexico, the West Indies and Bahamas, and as far as Bermuda in 1616 [7]. Papaya was taken to the Caribbean and Southeast Asia first and then spread to India, Oceania, and Africa [8].

Papaya plants may reach a height of $9 \mathrm{~m}$ [9]. Thus, papaya is considered a giant herb [10]. However, the stem is semi-woody since lignin accumulation in the cell wall is at an intermediate level between Arabidopsis and poplar [11]. Similar to poplar, the increasing number of genes associated with cell expansion in papaya is consistent with larger plants and is associated with lignin biosynthesis showing a convergent evolution of a tree-like habit.

Papaya plants have a rapid growth rate and usually a short-life (2 to 3 years) but can produce fruit for more than 20 years [10]. Papaya is typically single-stemmed, although branching can occur with age or if the apex is removed [12]. Cultivated papaya trees in Brazil are usually replaced before exceeding 3-4m in height. Hollow petioles up to $1 \mathrm{~m}$ long bear simple leaves with deep lobes. Leaves may be up to $70 \mathrm{~cm}$ in diameter [13].

The papaya has a rather complicated means of reproduction [13]. Plants are male, hermaphrodite, or female. The flowers are born either singly (usually female and hermaphrodite) or in large clusters (male) in leaf axils [13]. Plants flower and fruit continuously after flower initiation commences and the leaves generally senesce and abscise before the fruit reaches maturity [14].

Commercial papaya cultivation is restricted to tropical and subtropical areas due to chilling damage at temperatures above freezing [15]. However, there is growing interest in this crop for cooler areas, such as Spain, Israel, Argentina, Australia and Japan. For instance, papaya has been grown outdoors in the southern republics of the former Soviet Union Kapanadze \& Khasaya [16] and as an annual crop in the southeastern United States [15]. Over 350 ha are cultivated in the Canary Islands ISTAC [17], where the crop is mostly (90\%) planted under greenhouses (Figure 1), covered either by mesh or polyethylene film to prevent infection of papaya ring spot virus (PRSV) and to benefit from the controlled climatic conditions required for good quality fruit $[18,19]$ and high annual yields in the range of $200 \mathrm{t} \mathrm{ha}^{-1}$ in a 22 months cycle (Julian Cuevas Gonzalez, personal communication). Commercial plantings of papaya in Australia occur throughout coastal tropical and subtropical regions of New South Wales, Queensland and Western Australia, with Queensland accounting for $>95 \%$ of production [20].

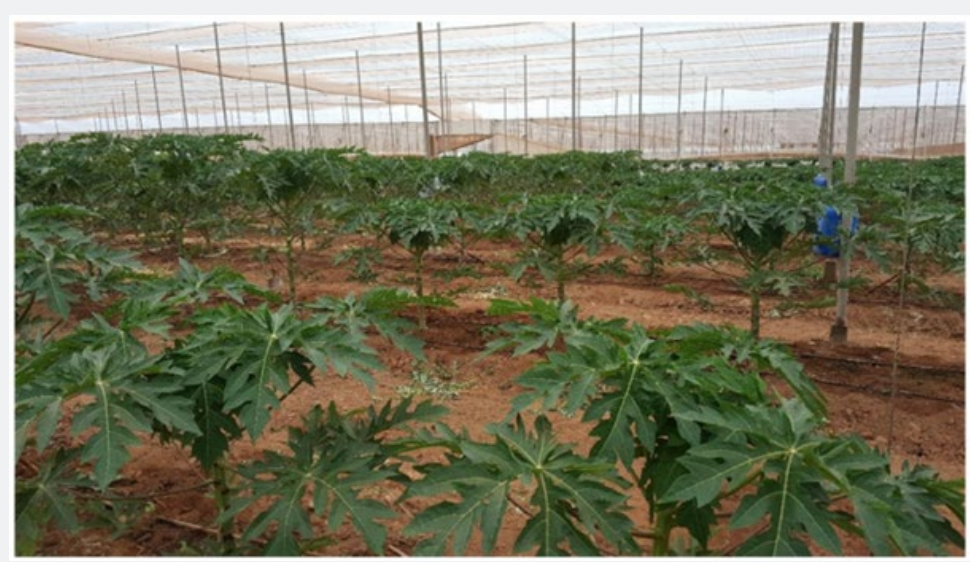

Figure 1: Commercial scale protected papaya plantations in the Canary Islands.

The study of light effects on photosynthetic carbon assimilation is important because papaya cultivation is increasing under protected structures, such as the plantations located on the Canary Islands and in the South of Spain, Turkey [21,22]. Thus, it is important to construct protective structures that could allow better light distribution within canopy in order to optimize photosynthesis and subsequent impacts on plant growth and yield. In areas where protected structures are used for papaya production, attacks by aphids which transmit PRSV are better controlled. Additionally, against wind, hail and excess solar radiation in order to satisfy papaya light requirements and at the same time obtain high yield of extraordinary quality. Yet, plant water use is decreased in protected structures since evapotranspiration is reduced by c.a. $25 \%$. Fruit yield and quality have also been observed to increase when papaya is grown under protected structures [19]. Another important aspect of knowing the optimum quantities of light for optimal physiological functioning of papaya is that plant spacing can be adjusted for maximum light distribution inside the canopy. Maximum light interception is obtained with very large plant spacing (and training and pruning that is not the case for papaya). But leaving optimum captation of light to very few plants leads to poor yield (although of high quality). The trend in orchard design is the contrary, plant many trees although light interception is not so good. Different tools are in use to make better what is not optimum. What growers do is to reach a compromise between high number of plants and optimum 
radiation. The spacing then results from reaching maximum yield per unit area seeking for the maximum profits.

Moreover, light management strategies such as painting inside the greenhouse with surfaces white, covering the soil with white mulching plastic, whitening the roof of plastic greenhouses, removal of the oldest leaves, or applying whitewash (processed kaolinite clay) to the leaf surfaces, can be implemented for maximum light absorption by the canopy [23-25]. Thus, the challenge for papaya production will be to increase high quality fruit production in current planted areas and marginal sites where the abiotic environment is limiting. The aim of this short review is show the state of art related to light effects on both photosynthetic capacity and growth of papaya plant.

\section{Discussion}

\section{Light}

The term "light" is often defined as the electromagnetic radiation perceived by the human eye (wavelength: $380-760 \mathrm{~nm}$ ). However, in the field of physics, it refers to a wider range of electromagnetic radiation ranging from ultraviolet $(10-380 \mathrm{~nm})$ to infrared $\left(760 \mathrm{~nm}^{-1} \mathrm{~m}\right)$ [26] (Figure 2). The photosynthetic reactions of plants are driven by light at wavelengths between 400 and $700 \mathrm{~nm}$, known as photosynthetic active radiation (PAR, $\mu \mathrm{mol}$ photons $\mathrm{m}^{-2} \mathrm{~s}^{-1}$ ) [26]. In this short review, the term "light" (PAR) is defined as the electromagnetic radiation which causes photochemical reactions in plants.

\section{The Electromagnetic Spectrum}

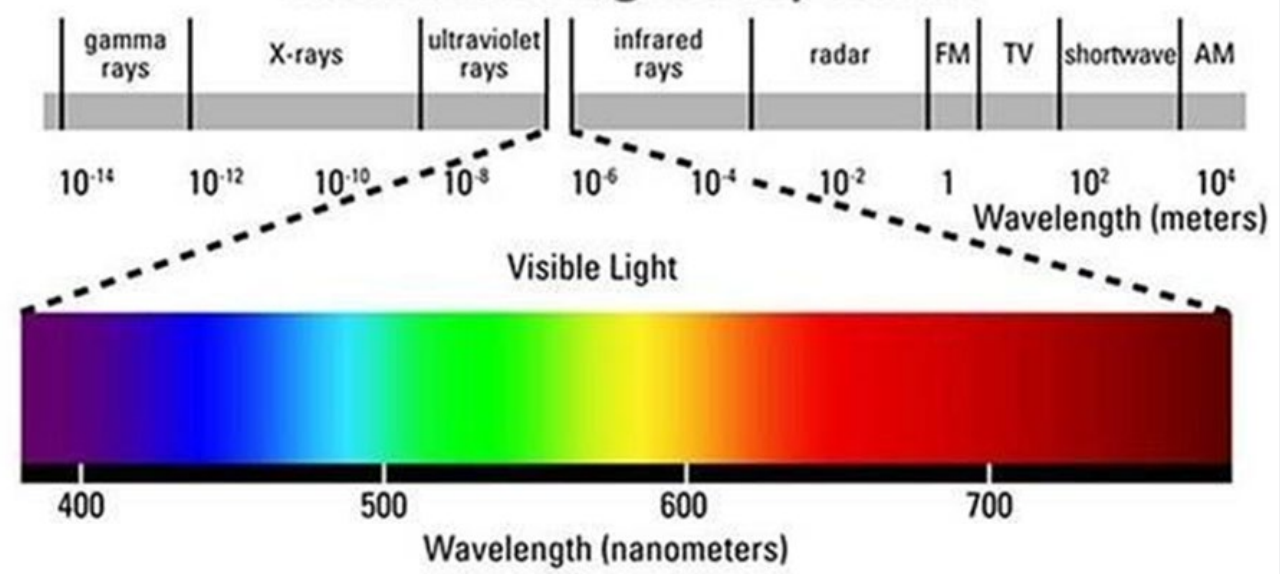

Figure 2: Electromagnetic spectrum. The visible portion of the electromagnetic spectrum is just a tiny portion of the full spectrum.

Papaya is a light-demanding plant and prolonged low light intensity can cause significant alterations in the leaf anatomy and morphology [27]. Buisson \& Lee [27] studied the effects of light intensity and light quality on morphology and growth of papaya. In one treatment, they reduced light intensity by $70 \%$ (using screens) and in another treatment, they also sharply reduced the Red/far Red ratio (R/fR). Compared to plants cultivated in full sunlight, these treatments caused reductions in leaf thickness, specific leaf weight, stomatal density, leaf area and petiole length, as well as increased chlorophyll content per unit leaf area and the amount of air space into the leaf mesophyll. The reduction in light intensity also greatly reduced the number of lobules on the leaf. The presence of more lobules in leaves of papaya grown in full sunlight compared to those in $70 \%$ shade may be associated with an increased amount of leaf surface in contact with the air, which increases leaf cooling.

The light saturation point [the light intensity where net photosynthetic rate $(\mathrm{Pn})$ reaches its maximum] of papaya leaves is dependent on plant age and growth conditions. For example, in individual leaves formed in full sunlight $\left(13^{\text {th }}\right.$ to $14^{\text {th }}$ leaf below the apex) and conditions of adequate water and nutrient availability, photosynthetic carbon assimilation in six-month-old plants is saturated at around $2000 \mu \mathrm{mol}$ photons $\mathrm{m}^{-2} \mathrm{~s}^{-1}$ [28]. However, in young papaya (three-month-old) leaves grown under full sunlight at $1250 \mu \mathrm{mol}$ photons $\mathrm{m}^{-2} \mathrm{~s}^{-1}$ maximum light intensity, the light saturation point is lower, at c.a. $1100 \mu \mathrm{mol}$ photons $\mathrm{m}^{-2} \mathrm{~s}^{-1}$ [12]. In four-month-old plants grown in a greenhouse, at $1200 \mu \mathrm{mol}$ photons $\mathrm{m}^{-2} \mathrm{~s}^{-1}$ maximum light intensity with adequate water supply and VPDair of about $1 \mathrm{kPa}$, light saturation of the mature leaf $\left(10^{\text {th }}\right.$ leaf below the apex $)$ was $1000 \mu \mathrm{mol}$ photons $\mathrm{m}^{-2} \mathrm{~s}^{-1}[29]$.

Reduced light intensity can cause a significant decrease in photosynthetic carbon assimilation in papaya [28- 30]. Although PAR is very important for photosynthesis, excess light energy can also decrease carbon assimilation by the leaf. When the light source is solar radiation, this decrease in the Pn under excessive radiation conditions is caused by the interaction of stomatal and non-stomatal factors. High solar radiation can cause leaf heating, increase the vapor pressure deficit between the leaf surface and surrounding air (VPDleaf-air) and promote stomatal closing, reducing $\mathrm{CO}_{2}$ entry into the leaf mesophyll, thus diminishing the concentration of $\mathrm{CO}_{2}$ at the Rubisco carboxylation sites. Nonstomatal effects associated with lower photosynthetic carbon 
assimilation under excess solar radiation are due, in part, to photoinhibition, whereby photosystem II (PSII) is damaged [31,32]. This destruction sharply reduces photochemical efficiency, with damage to ATP and NADPH synthesis [31]. An interaction between supra-optimal leaf temperatures and photochemical efficiency can also be observed, because temperatures above $44^{\circ} \mathrm{C}$ increase the initial fluorescence emission by excited chlorophyll a in the antennae structure of the PS II (F0), thus reducing the photochemical efficiency [33].

Wang et al. [30] reported that the leaves located on the lower part of papaya canopy cultivated under protected system $\left(35^{\text {th }}\right.$ to $45^{\text {th }}$ leaf below the apex) received only c.a $20 \%$ of the solar radiation that reached leaves in the upper portion of the canopy $\left(13^{\text {th }}\right.$ to $20^{\text {th }}$ leaf below the apex). Thus, in protected structures, removing leaves located in the lower part of the canopy can reduce the number of sinks in the plants and reduce transpiration, thereby lowering plant water uptake and allocating transpiration and mineral nutrient to the upper leaves in the canopy. These upper leaves have a higher Pn, because they receive a greater amount of light. To effectively implement these light maximization strategies in protected systems, it is necessary to determine the effects of light intensity on the photosynthetic process.

Knowledge of the optimum light intensities for maximum photosynthetic efficiency of papaya provides a basis for reducing excess solar energy in field plantations. When adequate light intensities are known, actions such as applying particle films to the leaves $[24,25]$, to prevent light damage to the photochemical apparatus and increased leaf temperature, can be implemented to provide adjustments to the quantity of solar radiation absorbed by the leaf lamina. Excess light energy can be considerably more harmful to the photochemical apparatus of water-stressed papaya plants than to well-watered plants. In papaya plants grown with low water availability (soil water tension of $-68 \mathrm{kPa}$ ), the light saturation point was significantly decreased, showing that under field conditions, the optimal light intensity can also be altered by the amount of water in the soil [28]. If water availability is limited, particle films are more effective at protecting leaves from photochemical damage, because such particles increase excess light energy reflection in locations where there is intense solar radiation [24,25].

In addition to the light saturation point for optimum Pn being an important consideration, other variables related to light intensity such as the light compensation point (the light intensity at which $\mathrm{Pn}$ is and a quantum yield (defined as the molar amount of $\mathrm{O}_{2}$ evolved or $\mathrm{CO}_{2}$ absorbed per mol of photons absorbed by the photosynthetic apparatus) are important for papaya production. In mature leaves $\left(13^{\text {th }}\right.$ and $14^{\text {th }}$ leaf below the apex) of six-monthsold papaya plants grown in the field without water limitation, the light compensation point was 27, 29 and $30 \mu \mathrm{mol}$ photons $\mathrm{m}^{-2} \mathrm{~s}^{-1}$ for papaya cultivars

'Tainung 2', 'Red Lady' and 'Sunrise', respectively [28]. Under such condition, the values of incident quantum yield ( $\Phi \mathrm{i})$ were
$0.039,0.041$ and $0.040 \mu \mathrm{mol} \mathrm{CO}_{2} \mu \mathrm{mol}$ photons leaf ${ }^{-1}$, respectively for each cultivar. In 103-days-old 'Golden' papaya plants grown in a greenhouse when soil water was not limited and maximum PAR was $1000 \mu \mathrm{mol}$ photons $\mathrm{m}^{-2} \mathrm{~s}^{-1}$, $\mathrm{Ii}\left(\mathrm{CO}_{2}\right.$ assimilation for each photon unit that reaches the papaya leaf lamina was $0.034 \mu \mathrm{mol}$ $\mathrm{CO}_{2} \mu$ mol photons ${ }^{-1}$ leaf $^{-1}$ [34]. In leaves of $\mathrm{C}_{3}$ plants, including papaya, without water limitation the mean $\Phi \mathrm{i}$ was $0.053 \mu \mathrm{mol} \mathrm{CO}_{2}$ $\mu$ mol photons ${ }^{-1}$ [35]. In the leaves of two papaya varieties (UENF Caliman 01 and Golden) ( $6^{\text {th }}$ leaf below the apex) cultivated in a greenhouse with adequate water, the compensation irradiance (Ic; the minimum light intensity limit on the leaf lamina where photosynthetic carbon assimilation is positive,) was $100 \mu \mathrm{mol}$ photons $\mathrm{m}^{-2} \mathrm{~s}^{-1}$ [29]. At light intensities below this Ic value, the $\mathrm{CO}_{2}$ release rate (respiration) is higher than $\mathrm{CO}_{2}$ assimilation (photosynthesis). The $\Phi \mathrm{i}$ and Ic values are extremely important in protected cultivations, because knowing these values can be important in choosing planting spacing, greenhouse design for protected cultivation and in canopy management strategies, i.e., removal of very shaded leaves located in the lower part of the canopy, as reported previously [30]. In leaves at different positions within the canopy of different papaya cultivars, high Ic values indicate more sensitivity of a particular cultivar to shading.

Knowledge of the $\Phi$ i values for optimal papaya plant growth is important because cultivars that have high $\Phi$ i value have a higher $\mathrm{CO}_{2}$ assimilation rate in environments where the light intensity (PAR) is high. This is important in tropical regions where papaya is cultivated. In these regions, there is a higher predominance of clouds, which can cause intense fluctuations in light energy absorbed by the leaf lamina [36]. Normally, high $\Phi$ i values are associated with lower Ic values. This is important for breeding programs since genetically improved papaya cultivars with high $\Phi \mathrm{i}$, and low Ic values.

The stomata of papaya are very sensitive to fluctuations in light intensity Clemente \& Marler [37], which is strongly reflected in the $\Phi \mathrm{i}$ values. When light intensity is reduced quickly, the stomata close at a rate of $3 \mathrm{mmol} \mathrm{m}^{-2} \mathrm{~s}^{-1}$ Clemente \& Marler [37], which is a very high stomata closing rate. This value was obtained when papaya leaves receiving $2000 \mu \mathrm{mol}$ photons $\mathrm{m}^{-2} \mathrm{~s}^{-1}$ were suddenly exposed to a reduced light intensity of $300 \mu \mathrm{mol}$ photons $\mathrm{m}^{-2} \mathrm{~s}^{-1}$. This shows the sensitivity of this species to shading which is very important when growing papaya under protected cultivation, because in these environments light can be limited by the type of structure and the plastic cover used. An important consideration is that water shortage in the soil can raise the rate at which the stomata close when the intensity of light impacting the papaya leaf lamina is reduced Clemente \& Marler [37].

\section{Light interception effects on papaya physiology}

Plant spacing can significantly influence light interception by crop plants, affects the impact of weed competition and alters morphophysiological characteristics of the plants with significant effects on final crop yield and quality. Light interception by crop canopies is determined by planting density, planting pattern, 
and morphological characteristics of the component species [38]. Full coverage is achieved most rapidly when: 1) population density is high, 2) seedlings partition a significant proportion of new assimilate to leaf development, 3) specific leaf weight is small, and 4) leaf angle is low. The interception of radiation and early productivity are then maximal and the crop is also able to shade out shorter weed competitors. Highly productive canopies have the characteristics of full cover and erect leaves, at least at the top of the canopy [38]. However, in papaya plant the spiral leaf insertion on the trunk, associated with a long petiole, allows efficient light distribution in the papaya canopy [39] (Figure 3).

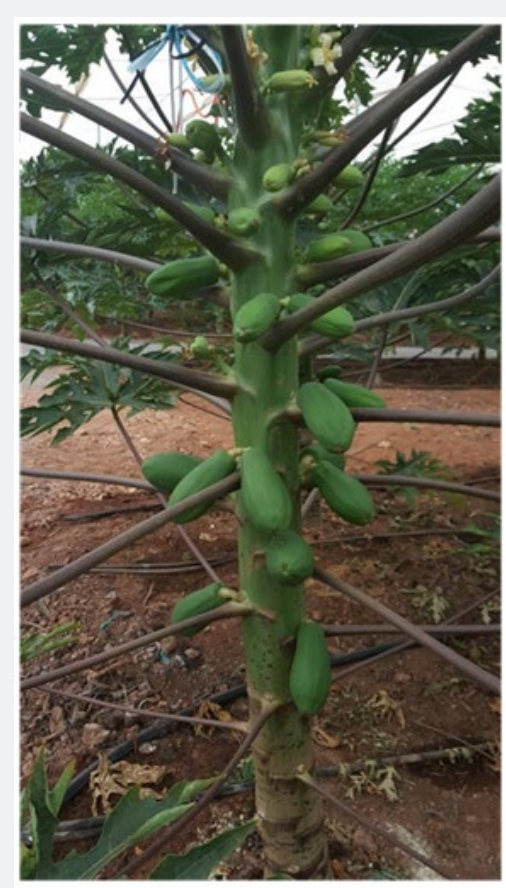

Figure 3: Phyllotaxis of the papaya plant. The spiral leaf insertion on the trunk.

In India, different spacing are being adopted in different traits for different papaya cultivars [40]. For example, with 'Coorg Honey Dew' papaya, maximum fruits plant ${ }^{-1}$ and fruit yield plant ${ }^{-1}$ were obtained with 2267plants ha ${ }^{-1}$ and the minimum with 3703 plants $\mathrm{ha}^{-1}$. A plant population of 4629 plants $\mathrm{ha}^{-1}$ produced the maximum fruit yield ha ${ }^{-1}$, whereas 2267 plants ha- ${ }^{-1}$ produced the minimum. An increasing plant density reduced the average fruit weight. The benefit/cost ratio was maximum (2.44:1) with 2267plants ha ${ }^{-1}$, and minimum (1.67:1) with 4444plants ha ${ }^{-1}$. Plant height and girth were non-significantly different among different plant densities

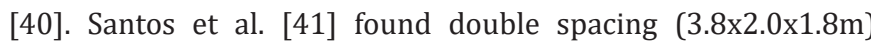
promoted greater interception of PAR and increased PAR-use efficiency compared to single spacing $(3.8 \times 2.0 \mathrm{~m})$. At the same time, fruit yield in double spaced plants was higher than in single spaced plants, showing that under double spacing, papaya plants intercepted more PAR with higher efficiency [42].

\section{Conclusion}

Light, as discussed in the present short review, can control photosynthetic processes and affect papaya plant growth. Thus, regardless of whether papaya is grown under either field or protected cultivation, understanding this important environmental factor on photosynthetic carbon assimilation is extremely important for commercial papaya production. Finally, information included in this review could greatly aid in future papaya breeding efforts, as well as could facilitate agricultural site selection for future papaya cultivation.

\section{Acknowledgement}

We thank the Coordination for University Personnel Training (Coordenação de Aperfeiçoamento de Pessoal de Nível Superior (CAPES), the National Council for Scientific and Technological Development (CNPq), the Foundation for Research Support of Rio de Janeiro state (Fundação de Amparo à Pesquisa do Estado do Rio de Janeiro (FAPERJ)), and the Study and Projects Financier (Financiadora de Estudos e Projetos (FINEP)) for financial support of the research.

\section{References}

1. FAOSTAT (2014) FAO data for agriculture: statistics database.

2. Dunne J, Horgan L (1992) Meat tenderizers. In: Hui YH (Ed.), Encyclopedia of Food Science and Technology. Wiley, New York, USA, pp. 1745-1751.

3. El Mousaaoui, Nijs A, Paul M, Wintjens C, Vincentelli R, et al. (2001) Revisiting the enzymes stored in the laticifers of Carica papaya in the context of their possible participation in the plant defense mechanism. Cell Mol Life Sci 58(4): 556-570.

4. USDA (2017).

5. Ali M, Lazan H (1998) Papaya. In: Shaw PE, Chan HJ, Jr Nagy S (Eds.), Tropical and Subtropical Fruits. Agscience Inc Florida USA, pp. 401445.

6. Watson B (1997) Agronomy/agroclimatology notes for the production of papaya.

7. Morton J (1987) Fruits of warm climates. Creative Resource Systems, Miami, Florida, USA, pp. 336-346.

8. Crane JH (2005) Papaya growing in the Florida Home Landscape. University of Florida. IFAS Extension Publication, p. 8.

9. Campostrini E, Glenn DM, Yamanishi OK (2010) Papaya: ecophysiology of growth and production. In: DaMatta F (Ed.) Ecophysiology of tropical tree crops. Nova Science Publishers, New York, USA, pp. 287-307.

10. Malo SE, Campbell CW (1986) The papaya. Gainesville: University of Florida, Cooperative Extension Service Fruits Crops Fact Sheet FC-11.

11. Ming R, Hou S, Feng Y, Yu Q Dionne-Laporte A, et al. (2008) The draft genome of the transgenic tropical fruit tree papaya (Carica papaya Linnaeus). Nature 452: 991-997.

12. Marler TE, Mickel MV, Quitugua R (1993) Papaya Ringspot Virus Influences Net Gas Exchange of Papaya Leaves. Hort Science 28: 322324.

13. Marler TE, George AP, Nissen RJ, Andersen P (1994) Miscellaneous tropical fruits. In: Schaffer B, Andersen PC (Eds.), Handbook of 
environmental physiology of fruits crops. Volume II, Subtropical and tropical crops, CRC Press, Florida, USA, pp. 199-224.

14. Zhou L, Christopher DA, Paull R (2000) Defoliation and fruit removal effects on papaya fruit production, sugar accumulation, and sucrose metabolism. J Amer Soc Hort Sci 125: 644-652.

15. Yadav UL, Burris AJ, Mccarry D (1990) Papaya: a potential annual crop under middle Georgia conditions. In: Janick J, Simon JE (Eds.), Advances in New Crops. Timber Press, Oregon, USA, pp. 364-366.

16. Kapanadze I, Khasaya GS (1988) Some characteristics of pawpaw trees. Subtropicheskie Kul'tury 1: 136-140.

17. ISTAC (2017) Instituto canario de estadística.

18. Galan S, Farre Massip VG, JMF (2006) Tropical and subtropical fruit production in Spain. Chronica Hortic 46: 26-30.

19. Galan S, Rodriguez Pastor VG, MCR (2007) Greenhouse cultivation of papaya. Acta Hortic 740: 191-195.

20. Garret A (1995) The pollination biology of papaw (Carica papaya L.) in Central Queeensland. PhD Thesis, Central Queensland University, Rockhampton, Australia.

21. Gunes E, Gubbuk H (2012) Growth, yield and fruit quality of three papaya cultivars grown under protected cultivation. Fruits 67: 23-29.

22. Campostrini E, Schaffer B, Ramalho JD, Gonzalez JC, Rodrigues WP, et al. (2018) Environmental factors controlling carbono assimillation, growth, and yield of papaya (Carica papaya L.) under water-scarcity scenarios. In: Tejero IFG, Zuazo VHD (Eds.), Water scarcity and sustainable agriculture in semiarid environment. Academic Press, London, UK, pp. 481-505.

23. Glenn DM, Drake S, Abbott JA, Puterka GJ, Gundrum P (2005) Season and cultivar influence the fruit quality response of apple cultivars to particle film treatments. Hort Technology 15(2): 249-253.

24. Glenn DM, Puterka GJ (2010) Particle Films: A New Technology for Agriculture. Hortic Rev 31: 1-24.

25. Sharma RR, Vijay RR, Datta S (2015) Particle films and their applications in horticultural crops. Appl Clay Sci 116-117: 54-68.

26. Fujiwara K, Kozai T (1995) Physical microenvironment and its effects. In: Aitken CJ, Kozai T, Smith MAL (Eds.), Automation and Environmental Control in Plant Tissue Culture. Kluwer Academic Publishers, Dordrecht, Netherlands, pp. 319-369.

27. Buisson D, Lee DW (1993) The development responses of papaya leaves to simulated canopy shade.

Am J Bot 80(8): 947-952.

28. Marler TE, Mickelbart MV (1998) Drought, leaf gas exchange, and chlorophyll fluorescence of field grown papaya. J Amer Soc Hort Sci 123(4): 714-718.
29. Pecanha AL (2010) Metabolismo fotossintético, crescimento e estado nutricional do mamoeiro (Carica papaya L.) em resposta à condutividade elétrica da solução de cultivo. PhD Thesis, UENF, Campos dos Goytacazes, RJ, Brazil.

30. Wang H, Long L, Kumar A, Wang W, Schemm JKE, et al. (2014) How well do global climate models simulate the variability of Atlantic tropical cyclones associated with ENSO? J Climate 27: 5673-5692.

31. Vass I (2012) Molecular mechanisms of photodamage in the photosystem II complex. Biochim Biophys Acta 1817(1): 209-217.

32. Goh CH, KO SM, Koh S, Kim YJ, Bae HJ (2012) Photosynthesis and environments: photoinhibition and repair mechanisms in plants. J Plant Biol 55(2): 93-101.

33. Weng J, Lai M (2005) Estimating heat tolerance among plant species by two chlorophyll fluorescence parameters. Photosynthetica 43(3): 439-444.

34. Lima RSN (2014) Irrigação parcial do sistema radicular e déficit de irrigação regulado em mamoeiro (Carica papaya L.): capacidade fotossintética, crescimento e eficiência no uso daágua. PhD Thesis, UENF, Campos dos Goytacazes, RJ, Brazil.

35. Bjorkman O, Demming B (1997) Photon yield of $\mathrm{O}_{2}$ evolution and chlorophyll fluorescence characteristics at $77 \mathrm{~K}$ among vascular plants of diverse origins. Planta 170(4): 489-504.

36. Way DA, Pearcy RW (2012) Sunflecks in trees and forests: from photosynthetic physiology to global change biology. Tree Physiol 32(9): 1066-1081.

37. Clemente HS, Marler TE (1996) Drought stress influences gas-exchange responses of papaya leaves to rapid changes in irradiance. J Amer Soc Hort Sci 121(2): 292-295.

38. Loomis RS, Connor DJ (1992) Crop ecology: productivity and management in agricultural systems. Cambridge University Press, Cambridge, England, p. 538.

39. Ferraz TM, Rodrigues WP, Torres N, Reis A, Pecanha FO, et al. (2016) Comparison between single-leaf and whole-canopy gas exchange measurements in papaya (Carica papaya L.). Plants Sci HorticAmsterdam 209: 73-78.

40. Reddy YTN (1995) Effect of plant spacing on 'Coorg Honey Dew" papaya (Carica papaya). Indian J Agric Sci 65(2): 130-132.

41. Santos EM, Junior S, Cavalcante ÍHL, Marques AS, Albano FG (2016) Planting spacing and NK fertilizing on physiological indexes and fruit production of papaya under semiarid climate. Bragantia 75(1): 63-69.

42. Food and Nutrition Board, Institute of Medicine, National Academies (2017).

\begin{tabular}{l} 
Your next submission with Juniper Publishers \\
will reach you the below assets \\
- Quality Editorial service \\
- Swift Peer Review \\
- Reprints availability \\
- E-prints Service \\
- Manuscript Podcast for convenient understanding \\
- Global attainment for your research \\
- Manuscript accessibility in different formats \\
( Pdf, E-pub, Full Text, Audio) \\
- Unceasing customer service \\
Track the below URL for one-step submission \\
https://juniperpublishers.com/online-submission.php \\
\hline
\end{tabular}

